\title{
Immunoglobulin Kappa Locus
}

National Cancer Institute

\section{Source}

National Cancer Institute. Immunoglobulin Kappa Locus. NCI Thesaurus. Code C26425.

This region represents the germline organization of the kappa light chain locus. The locus includes V (variable), J (joining), and C (constant) segments. During B cell development, a recombination event at the DNA level joins a single $V$ segment with a J segment; the C segment is later joined by splicing at the RNA level. Recombination of many different $\mathrm{V}$ segments with several J seg ments provides a wide range of antigen recognition. Additional diversity is attained by junctional diversity, resulting from the random additional of nucleotides by terminal deoxynucleotidyltransferase, and by somatic hypermutation, which occurs during B cell maturation in the spleen and lymph nodes. (from LocusLink) 